\title{
Strategi Pengembangan Industri Tenun Endek melalui Pendekatan One Village One Product di Kecamatan Sidemen Kabupaten Karangasem
}

\author{
I Gede Made Ramadiartha dan Ketut Dewi Martha Erli \\ Perencanaan Wilayah dan Kota, Fakultas Arsitektur Desain dan Perencanaan, \\ Institut Teknologi Sepuluh Nopember (ITS) \\ e-mail: erli.martha@urplan.its.ac.id
}

\begin{abstract}
Abstrak-Karangasem merupakan Kabupaten dengan tingkat kemiskinan tertinggi di Bali. Sidemen merupakan salah satu Kecamatan di Kebupaten Karangasem yang memiliki potensi Industri Tenun Endek. Adanya industri Tenun Endek dapat menyerap tenaga kerja lokal. Industri Tenun Endek merupakan produk khas daerah yang dapat menjadi potensi ekonomi wilayah. namun industri Tenun Endek memiliki masalah dalam pengembangannya dari segi bahan baku, proses produksi, manajemen penjualan dan pengrajin. Industri Tenun Endek terkonsentrasi di Kecamatan Sidemen oleh karena itu perlunya dilakukan studi pengembangan industri Tenun Endek melalui pendekatan One Village One Product. Dengan mingkatkan daya saing produk industri Tenun Endek sebagai industri dengan ciri khas daerah. Penelitian ini memiliki tiga tahapan yaitu mengidentifikasi karakteristik industri tenun endek dengan analisa kuantitatif deskriptif, menganalisa faktor-faktor eksternal dan internal yang mempengaruhi perkembangan industri endek di Kecamatan Sidemen Kabupaten Karangasem dengan analisa stakeholder, analisa likert dan analisa SWOT kemudian merumuskan strategi pengembangan industri tenun endek dengan menggunakan analisa delphi. Hasil dari penelitian ini menunjukan bahwa strategi yang sesuai dengan kondisi industri Tenun Endek berada pada kuadran satu adalah growth strategy pada matriks SWOT sehingga mampu memaksimalkan kekuatan internal untuk mengembangkan peluang yang ada. Strategi dirumuskan menjadi delapan strategi utama dan lima strategi pendukung untuk pengembangan Industri Tenun Endek di Kecamatan Sidemen Kabupaten Karangasem. Strategi utama dalam pengembangan industri tenun endek berfokus kepada peningkatan kualitas produksi dan manajemen pemasaran produk yang lebih luas untuk menjangkau pasar yang lebih luas.
\end{abstract}

Kata Kunci-One Village One Product, Industri Tenun Endek Sidemen, Produk Khas Sidemen.

\section{PENDAHULUAN}

$\mathrm{P}$ ENGEMBANGAN wilayah pada dasarnya mempunyai tujuan agar suatu wilayah berkembang menuju tingkat perkembangan yang diinginkan. Pengembangan wilayah dilaksanakan melalui optimasi pemanfaatana sumberdaya yang dimilikinya secara harmonis, serasi dan terpadu. Suatu wilayah dapat berkembangan melalui berkembangnya sektor ungg|ulan pada wilayah tersebut dapat mendorong perkembangan sektor lain[1]. Pengembangan wilayah dalam jangka panjang lebih ditekankan pada pengenalan potensi sumber daya alam dan potensi pengembangan lokal wilayah mendukung pertumbuhan ekonomi dan kesejahteraan sosial masyarakat, termasuk pengentasan kemiskinan, serta upaya mengatasi kendala pembangunan yang ada di daerah dalam rangka mencapai tujuan pembangunan.
Kabupaten Karangasem merupakan salah satu kabupaten di Provinsi Bali, dengan wilayah administrasinya yang terdiri atas delapan kecamatan, tiga kelurahan dan tuju puluh lima desa. Kabupaten Karangasem merupakan kabupaten dengan tingkat kemiskinan tertinggi di Bali yaitu 7,44 \% atau setara dengan 30.330 jiwa di akhir 2015. Angka itu mengalami kenaikan cukup tajam dibandingkan 2012, sekitar 5,63\% atau setara dengan 22.940 jiwa. Karangasem sendiri merupakan daerah dengan tingkat kemiskinan tertinggi di Bali dan mengalami peningkatan setiap tahunnya [2]. Kecamatan Sidemen merupakan salah satu Kecamatan miskin diantara delapan Kecamatan di Kabupaten Karangasem, Kecamatan Sidemen memiliki produk khas lokal yaitu Tenun Endek yang dapat meningkatkan perekonomian masyarakat dengan mengembangkan Industri Tenun Endek.

Dalam perkembangannya, keberadaan Industri Tenun Endek berkurang setiap tahunya saat ini jumlah Industri Tenun Endek sebesar dua puluh unit industri penurunan ini disebabkan karena rendahnya daya saing produk Tenun Endek dipasaran. Rendahnya daya saing ini dikarenakan beberapa faktor terkait mulai dari kualitas tenun endek, pengemasan dan harga tenun endek yang berubah-ubah [3]. Peran industri sendiri dalam perekonomian Karangasem PDRB Karangasem Seri 2010 Menurut Lapangan Usaha mencatat pada tahun 2010 sumbangan sektor industri kepada PDRB sebesar Rp. 287.496.370.000 pada tahun 2011 sebesar Rp. 302.804.160.000 pada tahun 2012 sebesar Rp. 332.726.130.000 pada tahun 2013 sebesar Rp. 375 524.870.000 pada tahun 2014 sebesar Rp. 432.722.060.000 pada tahun 2015 sebesar Rp. 506.182.280.000 pada tahun 2016 sebesar Rp. 550.021.290.000 sehingga peran sektor industri dalam PDRB Karangasem 4,2\% di tahun 2010 menjadi 5,04\% ditahun 2016. Peran sektor Industri Sidemen terhadap PDRB Industri Pengolahan di Kabupaten Karangasem senilai 14,8 \% di tahun 2010 dan meningkat hingga 15,5\% di tahun 2016 [4], [5].

Maka dari itu diperlukan pendekatan yang berbasis inovasi untuk mengembangkan perekonomian Tenun Endek sendiri mulai dari produksi hingga ke pemasaran sehingga memiliki daya saing yang lebih baik di pasaran, dengan pendekatan One Village One Product diharapkan mampu menguatkan produk daerah agar mampu berkembang dan berdaya saing di Pasaran. Pendekatan One Village One Product pertama kali diinisiasi di Oita, Jepang, OVOP merupakan suatu pendekatan pengembangan potensi daerah di satu wilayah untuk menghasilkan produk yang mampu bersaing di pasar global, dengan tetap memiliki ciri khas keunikan karakteristik dari daerah tersebut. Program One Village One Product ini 
telah berhasil dikembangkan di beberapa negara Asia seperti Jepang dan Taiwan, kini dicanangkan sebagai gerakan nasional di Indonesia. Penerapan OVOP di Indonesia dilaksanakan melalui program Kementerian Perindustrian sejak tahun 2008 untuk mengembangkan potensi Industri Kecil dan Menengah pada berbagai sektor. Penerapan program ini diharapkan dapat meningkatkan kesejahteraan penduduk dengan mengoptimalkan potensi sumberdaya lokal yang memiliki kemampuan bersaing pada pasar global[1].

Berbeda dengan pengembangan One Tambon One Product di Thailand yang sudah berhasil karena adanya faktor-faktor konsistensi pembangunan bertahap, keberpihakan pemerintah kepada pengusaha ekonomi lemah, koordinasi diantara para pelaku pembangunan, faktor rujukan dari raja dan pemanfaatan sumberdaya teknologi serta memiliki data base yang valid untuk memulai program. Sehingga produk yang dihasilkan memiliki daya saing tinggi di pasar global. Pendekatan OVOP dalam pengembangan ekonomi lokal wilayah menjadi perlu dipertimbangkan dalam strategi penguatan sektor IKM [6], [7].

Sementara sektor industri di Kabupaten Karangasem sangat kecil kontribusinya terhadap perekonomian wilayah. Sebagian besar kegiatan industri didominasi oleh industri kecil dan kerajinan rumah tangga. Kegiatan IKM ini dapat menyerap tenaga kerja yang cukup besar mencapai 27.709 orang untuk Kecamatan Sidemen kegiatan IKM menyerap 4.664 orang[4]. Perkembangan Jumlah IKM di Kecamatan Sidemen tercatat pada tahun 2015, terdapat 2.630 buah industri kecil. Jumlah ini meningkat 0,15 persen di bandingkan tahun sebelumnya yang mencapai 2.626 buah. Rumitnya permasalahan yang dihadapi industri sedang, membuat keberadaannya di kecamatan Sidemen sulit untuk dipertahankan. Adapun jumlah industri sedang tidak mengalami perubahan tetap berjumlah 3 semenjak tahun 2013 hingga 2015 produk-produk yang dihasilkan belum mampu bersaing pada pasar global[4]. Berbeda dengan karakteristik IKM di Jepang maupun Taiwan yang sudah memiliki orientasi ekspor serta terjalin kerjasama dengan usaha besar, sehingga produk yang dihasilkan memiliki daya saing tinggi di pasar global. Pendekatan OVOP dalam pengembangan ekonomi lokal wilayah menjadi perlu dipertimbangkan dalam strategi penguatan sektor IKM[7].

Kecamatan Sidemen merupakan Kecamatan dengan potensi sumberdaya alam dan sumberdaya manusia yang memiliki keahlian khusus dalam kelas menenun, serta merupakan salah satu wilayah destinasi pariwisata di Bali dimana dapat memanfaatkan kesempatan menciptakan sebuah hubungan yang saling menguntungkan di sektor industri tenun endek dan industri pariwisata. Namun produkproduk yang dihasilkan belum mampu bersaing pada pasar global. Adanya potensi sumberdaya lokal serta berkembangnya kegiatan IKM di Kabupaten Karangasem dan Kecamatan Sidemen khususnya memberikan peluang untuk menumbuhkan produk-produk lokal berdaya saing di pasar global. Peluang ini dapat berkontribusi terhadap penguatan ekonomi lokal serta peningkatan kesejahteraan masyarakat melalui Pendekatan One Village One Product yang berbasis pengembangan ekonomi lokal. Oleh karena itu, perlu dilakukan suatu kajian mengenai potensi daerah serta kelemahan, peluang dan ancaman yang dihadapi dalam pengembangan produk unggulan daerah dengan menggunakan Pendekatan One Village One Product agar memiliki nilai tambah dan daya saing[8].

\section{METODE PENELITIAN}

Penelitian ini bersifat kuantitatif dengan metode deskriptif untuk mengidentifikasi faktor yang mempengaruhi pengembangan Industri Tenun Endek. Data-data penelitian ini didapat dengan melakukan wawancara kepada keseluruhan pengrajin tenun endek dan stakeholder terpilih melalui perpaduan teknik sampling stakeholder analysis secara in-depth-interview. Wawancara dilakukan pada stakeholder baik dari pemerintah, pedagang maupun ketua adat yang terlibat dalam pengembangan industri tenun endek, sehingga proses dalam menggali faktor yang berpengaruh dalam pengembangan Industri Tenun Endek dapat sesuai tujuan penelitian[9].

\section{A. Variabel Penelitian}

Variabel penelitian yang digunakan untuk mengidentifikasi faktor-faktor yang mempengaruhi pengembangan Industri Tenun Endek dapat dilihat pada Tabel 1.

Tabel 1.

Variabel Penelitian Industri Tenun Endek

\begin{tabular}{ll}
\hline \hline \multicolumn{1}{c}{ Indikator } & \multicolumn{1}{c}{ Variabel } \\
\hline Sistem Produksi & Jumlah Tenaga Kerja \\
Industri & Kualitas Tenaga Kerja \\
& Strategi Pemasaran \\
& Teknologi Produksi \\
& Bahan Baku \\
& Kualitas Produk \\
Karakterisitik Produk & Volume Penjualan \\
& Jumlah Produksi \\
& Inovasi Produk \\
& Pengemasan Produk \\
& Air Bersih \\
Infrastruktur & Jalan \\
& Listrik \\
& Jumlah Pasar \\
& Pengolahan Limbah \\
& Jaringan Telekomunikasi \\
& Lembaga Permodalan \\
& Peran Pemerintah \\
& Kelompok Usaha \\
& Kerjasama antar pelaku usaha, pemerintah \\
& dan swasta \\
\hline \hline
\end{tabular}

\section{B. Metode Pengumpulan Data}

Pengumpulan data dalam penelitian menggunakan metode in depth interview yang diterapkan kepada seluruh sample terkait industri Tenun Endek metode tersebut dijelaskan sebagai berikut:

\section{Wawancara (in depth interview)}

Wawancara merupakan metode pengumpulan data dengan jalan tanya jawab sepihak yang dilakukan secara sistematis dan berlandaskan kepada tujuan penelitian. Wawancara telah terencana, dan mengacu pada tujuan penelitian untuk mengetahui variable terkait dan faktor faktor Kekuatan, Kelemahan Peluang dan ancaman dalam Industri Tenun Endek guna menjawab pemasalahan penelitian[9].

\section{Sample}

Sample dalam penelitian ini berasal daribertujuan untuk menemukan stakeholder yang meiliki pengaruh dan berkepenntingan tinggi dalam proses pengembangan Industri Tenun Endek di Kecamatan Sidemen, Kabupaten Karangasem[9]. 


\section{Metode Analisa}

Hasil data yang dikumpulkan akan dianalisa menggunakan masing metode sesuai dengan hasil akhir yang diperlukan metode tersebut antara lain:

\section{Analisa Stakeholder}

Analisa stakeholder dalam penelitian ini bertujuan untuk menemukan stakeholder yang meiliki pengaruh dan berkepenntingan tinggi dalam proses pengembangan Industri Tenun Endek di Kecamatan Sidemen, Kabupaten Karangasem.

\section{Analisa Likert}

Skala Likert mengukur faktor yang disusun menjadi itemitem instrumen yang dapat berupa pertanyaan atau pernyataan. Faktor yang digunakan dalam analisa likert ini adalah seluruh faktor terkait mengenai SWOT di Industri Tenun Endek Kecamatan Sidemen Kabupaten Karangasem [9].

\section{Analisa Efas dan Ifas}

Analisa EFAS dan IFAS merupakan Teknik analisa untuk mengukur bobot, rating dan skor faktor kekuatan, kelemahan, peluang, dan ancaman[9].

\section{Matriks SWOT}

Tujuannya merumuskan strategi umum atau grand strateg, adalah mengembangkan perusahaan dengan memanfaatkan hasil Analisa SWOT kedalam suatu format dengan memilih 5 hingga 10 faktor utama tiap kekuatan, kelemahan, peluang, dan ancaman. Dengan mengkaitkan satu faktor dengan faktor lainnya yang berada dalam satu kuadran[9].

\section{Analisa Delphi}

Delphi merupakan metode yang digunakan untuk membantu peneliti dalam menyusun pohon keputusan optimal seraya melakukan penilaian tentang bobot kepentingan setiap cabang alternatif penyelesaian masalah.

\section{HASIL DAN PEMBAHASAN}

\section{A. Identifikasi Karakteristik Industri Tenun Endek di} Kecamatan Sidemen

Karakteristik industri Tenun Endek didapat melalui wawancara secara langsung kepada seluruh Industri Tenun Endek. Untuk mengetahui produktivitas industri Tenun Endek di Kecamatan Sidemen, Kabupaten Karangasem dilakukan dengan menggunakan metode deskriptif kuantitatif. Mengetahui Sistem produksi industri Tenun Endek melalui jumlah tenaga kerja, kualitas tenaga kerja, Strategi pemasaran, teknologi produksi dan bahan baku industri Tenun Endek

Untuk mengetahui karakteristik produksi Industri Tenun Endek dilakukan dengan menganalisa variabel kualitas produk, volume penjualan, jumlah produksi, inovasi produk dan pengemasan produk peneliti secara langsung menilai dilapangan melihat bagaimana karakteristik produk yang dihasilkan Industri Tenun Endek saat ini.

\section{Jumlah Tenaga Kerja}

Jumlah tenaga kerja dapat bertambah dan berkurang dipengaruhi oleh volume produksi perbulan dari suatu Industri Tenun Endek, disaat mengerjakan suatu pesanan dengan jumlah besar yang membutuhkan waktu cepat Industri tenun endek akan menambah jumlah tenaga kerja untuk mempercepat waktu produksi.

\section{Kualitas Tenaga Kerja}

Pada umumnya pengrajin tenun endek menekuni pekerjaan ini secara turun menurun sehingga rata-rata tidak menekuni pendidikan formal

\section{Strategi Pemasaran}

Jenis pemasaran pengrajin Tenun Endek dibedakan menjadi dua jenis yaitu pemasaran secara offline pengrajin menunggu pembeli untuk datang ke toko atau Artshop dan pemasaran secara Online

\section{Teknologi Produksi}

Dalam proses produksi Tenun Endek pengrajin masih menggunakan teknologi yang bersifat tradisional yaitu Alat Tenun Bukan Mesin (ATBM). ATBM menjaga nilai ke khasan dari produk tenun endek Sidemen.

\section{Bahan Baku}

Bahan baku dalam produksi tenun endek dibagi menjadi dua jenis yaitu benang katun dan benang sutra. Bahan baku benang katun berasal dari luar daerah. Kemudian benang sutra adalah hasil pemintalan dari petani sutra di daerah Kecamatan Sidemen.

\section{Kualitas Produk}

Kualitas roduk dibagi menjadi 3 tingkatan dimana Kualitas A dengan komposisi 20\% katun 80\% sutra adalah kualitas terbaik dari tenun endek, kualitas B adalah kualitas sedang dengan komposisi masing-masing 50\% pada komposisi katun dan sutra dan yang terakhir adalah kualitas C dimana kualitas standar dengan komposisi 20\% kaun dan 80\% sutra.

\section{Volume Penjualan}

Volume penjualan yang di dapatkan oleh masing masing pengrajin tenun endek bervariasi, bergantung kepada teknik pemasaran, jumlah pesanan dan persaingan harga antar pengrajin satu dengan lainnya

\section{Jumlah Produksi}

Jumlah produksi dari tenun endek lebih meningkat ketika mendekati suatu event, untuk mempersiapkan produk yang bisa dijual di pekan pameran kesenian. Dalam sekali produksi endek yang dihasilkan perlembar berukuran 1,5 x 2,25 meter dengan motif yang berbeda ataupun sama tergantung dari pesanan pelanggan. Kemampuan produksi dari masing masing pengrajin bervariasi tergantung kepada penggunaan alat tenun bukan mesin, mesin dan jumlah tenaga kerja yang dimiliki dalam satu perusahaan.

\section{Inovasi Produk}

Perkembangan motif tenun endek bergantung kepada pemesan, karena pengrajin sendiri tidak memiliki kreatifitas yang cukup tinggi untuk mengembangkan motif tenun endek sendiri.

\section{Pengemasan Produk}

Dalam pengemasan setiap produknya, pengrajin tenun endek masih menggunakan pengemasan standar, dengan kertas label dan kantong plastik sebagai pembungkusnya.

\section{B. Faktor-faktor internal dan eksternal yang mempengaruhi pengembangan Industri Tenun Endek.}

Berdasarkan hasil pengumpulan data melalui wawancara ke seluruh sample, data yang didapatkan dirangkum menjadi faktor-faktor yang terkait dengan kekuatan, kelemahan, peluang dan ancaman yang dapat dilihat pada Table 2

Tabel 2.

Rangkuman Hasil Wawancara

\begin{tabular}{ccl}
\hline \hline Faktor & Kode & \multicolumn{1}{c}{ Deskripsi } \\
\hline $\begin{array}{l}\text { Kekuatan } \\
\text { (strength) }\end{array}$ & S1 & $\begin{array}{l}\text { Pekerja didominasi tenaga kerja lokal } \\
\text { Terdapat pengrajin dengan volume produksi yang } \\
\text { besar }\end{array}$ \\
& S3 & $\begin{array}{l}\text { Proses Produksi merupakan ke khasan turun } \\
\text { temurun warga lokal }\end{array}$ \\
& S4 & $\begin{array}{l}\text { Proses pertenunan tradisional dapat menjadi daya } \\
\text { tarik wisata } \\
\text { Terdapat produksi bahan mentah didalam } \\
\text { Produk yang memiliki ciri khas tertentu }\end{array}$ \\
& S6 & Produla
\end{tabular}




\begin{tabular}{|c|c|c|}
\hline Faktor & Kode & $\begin{array}{c}\text { Deskripsi } \\
\end{array}$ \\
\hline \multirow[t]{7}{*}{$\begin{array}{l}\text { Kelemahan } \\
\text { (weakness) }\end{array}$} & W1 & $\begin{array}{l}\text { Volume penjualan masih bergantung kepada } \\
\text { pemesanan }\end{array}$ \\
\hline & W2 & Tenaga kerja yang kurang terlatih \\
\hline & W3 & $\begin{array}{l}\text { Harga jual produk yang tingi karena proses yang } \\
\text { Panjang }\end{array}$ \\
\hline & W4 & Minim penggunaan mesin dalam proses produksi \\
\hline & W5 & $\begin{array}{l}\text { Produsen bahan baku tidak mampu memenuhi } \\
\text { permintaan dalam daerah }\end{array}$ \\
\hline & W6 & Tampilan kemasan kurang menarik \\
\hline & W7 & $\begin{array}{l}\text { Pengetahuan tentang strategi pemasaran yang } \\
\text { kurang }\end{array}$ \\
\hline \multirow{5}{*}{$\begin{array}{l}\text { Peluang } \\
\text { (opportunity) }\end{array}$} & O1 & Jalur distribusi barang yang baik \\
\hline & $\mathrm{O} 2$ & $\begin{array}{l}\text { Pemerintah dan swasta mendukung dengan } \\
\text { memperkenalkan dan menggunakan produk }\end{array}$ \\
\hline & O3 & Dekat dengan pusat kota \\
\hline & $\mathrm{O} 4$ & Jaringan telekomunikasi yang baik \\
\hline & O5 & $\begin{array}{l}\text { Belum terdapat pasar produk khusus didalam } \\
\text { daerah }\end{array}$ \\
\hline \multirow{5}{*}{$\begin{array}{l}\text { Ancaman } \\
\text { (threat) }\end{array}$} & $\mathrm{T} 1$ & Tidak terdapat pemerataan harga \\
\hline & $\mathrm{T} 2$ & Kurangnya pasar khusus didalam daerah \\
\hline & Т3 & Persaingan harga yang tidak sehat \\
\hline & $\mathrm{T} 4$ & $\begin{array}{l}\text { Minim bantuan modal untuk pengembangan } \\
\text { industri }\end{array}$ \\
\hline & T5 & $\begin{array}{l}\text { Pekerja memilijh pekerjaan yang lebih menjamin } \\
\text { diluar }\end{array}$ \\
\hline
\end{tabular}

Hasil rangkuman data selanjutnya akan dibentuk menjadi form likert yang akan dinilai melalui pertimbangan stakeholder terkait penelitian. Stakeholder tersebut adalah pakar yang terpilih melalui tahapan analisa stakeholder berdasarkan pertimbangan keperluan penelitian. Stakeholder yang terpilih dijelaskan pada table 3

Tabel 3

Hasil Analisa Stakeholder

\begin{tabular}{|c|c|c|c|c|}
\hline No & Stakeholder & Nama & Jabatan & Alasan \\
\hline $\mathrm{R} 1$ & Pemerintah & $\begin{array}{l}\text { Ibu I } \\
\text { Gusti } \\
\text { Ayu } \\
\text { Mas } \\
\text { Sumatri, } \\
\text { S.Sos. }\end{array}$ & $\begin{array}{l}\text { Bupati } \\
\text { Karangasem }\end{array}$ & \multirow{3}{*}{$\begin{array}{l}\text { Pihak yang } \\
\text { memetakan } \\
\text { perkembangan } \\
\text { industri dan } \\
\text { pengadaan pelatihan } \\
\text { pendampingan untuk } \\
\text { perkembangan } \\
\text { industri tenun endek } \\
\text { agar dapat formula } \\
\text { terbaik dalam } \\
\text { menglola masyarakat } \\
\text { dalam membentuk } \\
\text { usaha }\end{array}$} \\
\hline $\mathrm{R} 2$ & & $\begin{array}{l}\text { Bapak } \\
\text { Putu } \\
\text { Eka } \\
\text { Putra T }\end{array}$ & $\begin{array}{l}\text { Sekretaris } \\
\text { Bag. } \\
\text { Pembangunan }\end{array}$ & \\
\hline R3 & & $\begin{array}{l}\text { I Made } \\
\text { Suama, } \\
\text { SH }\end{array}$ & $\begin{array}{l}\text { Kepala Dinas } \\
\text { Perindustrian } \\
\text { dan } \\
\text { Perdagangan } \\
\text { Kabupaten } \\
\text { Karangasem }\end{array}$ & \\
\hline $\mathrm{R} 4$ & $\begin{array}{l}\text { Pelaku } \\
\text { Usaha }\end{array}$ & $\begin{array}{l}\text { Bapak } \\
\text { Wayan } \\
\text { Kawi }\end{array}$ & $\begin{array}{l}\text { Pemilik } \\
\text { Industri } \\
\text { Tenun Endek } \\
\text { Artanadi }\end{array}$ & $\begin{array}{lr}\text { Pihak } & \text { yang } \\
\text { menjalankan produksi } \\
\text { dari industri tenun } \\
\text { endek yang lebih }\end{array}$ \\
\hline R5 & & $\begin{array}{l}\text { Ibu } \\
\text { Dewa } \\
\text { Ayu } \\
\text { Kartika } \\
\text { Dewi }\end{array}$ & $\begin{array}{l}\text { Pengelola } \\
\text { Industri } \\
\text { Tenun Endek } \\
\text { Pelangi }\end{array}$ & $\begin{array}{l}\text { professional dalam } \\
\text { bidangnya } \\
\text { (Champion) agar } \\
\text { dapat memberikan } \\
\text { saran kepada pelaku } \\
\text { usaha lainnya. }\end{array}$ \\
\hline R6 & $\begin{array}{l}\text { Pemangku } \\
\text { Kepentingan } \\
\text { (Ketua Adat) }\end{array}$ & $\begin{array}{l}\text { Bapak } \\
\text { A.A. } \\
\text { Made } \\
\text { Agung } \\
\text { Surya } \\
\text { Jaya, } \\
\text { S.Sos. }\end{array}$ & $\begin{array}{l}\text { Camat } \\
\text { Kecamatan } \\
\text { Sidemen }\end{array}$ & $\begin{array}{l}\text { Pihak yang } \\
\text { mengetahui betul } \\
\text { perkembangan } \\
\text { masyarakatnya } \\
\text { sehingga mampu } \\
\text { mengarahkan dengan } \\
\text { baik }\end{array}$ \\
\hline
\end{tabular}

Selanjutnya form likert dibagikan kepada seluruh stakeholder untuk diberikan penilain, terkait kesesuain faktor yang dirangkum dengan kenyataan yang berada di lapangan. Hasil analisa likert disajikan pada table 4
Tabel 4.

Hasil Analisa Likert

\begin{tabular}{c|c|c|c}
\hline \hline IFAS & Total Nilai & Hasil \% & Status \\
\hline S1 & 24 & 100 & Sangat Setuju \\
\hline S2 & 24 & 100 & Sangat Setuju \\
\hline S3 & 24 & 100 & Sangat Setuju \\
\hline S4 & 24 & 100 & Sangat Setuju \\
\hline S5 & 23 & 95,83 & Sangat Setuju \\
\hline S6 & 23 & 95,83 & Sangat Setuju \\
\hline W1 & 22 & 91,66 & Sangat Setuju \\
\hline W2 & 24 & 100 & Sangat Setuju \\
\hline W3 & 23 & 95,83 & Sangat Setuju \\
\hline W4 & 20 & 83,33 & Sangat Setuju \\
\hline W5 & 24 & 100 & Sangat Setuju \\
\hline W6 & 24 & 100 & Sangat Setuju \\
\hline W7 & 24 & 100 & Sangat Setuju \\
\hline O1 & 24 & 100 & Sangat Setuju \\
\hline O2 & 23 & 95,8 & Sangat Setuju \\
\hline O3 & 24 & 100 & Sangat Setuju \\
\hline O4 & 18 & 75 & Setuju \\
\hline O5 & 24 & 100 & Sangat Setuju \\
\hline T1 & 24 & 100 & Sangat Setuju \\
\hline T2 & 24 & 100 & Sangat Setuju \\
\hline T3 & 24 & 100 & Sangat Setuju \\
\hline T4 & 24 & 100 & Sangat Setuju \\
\hline T5 & 24 & 100 & Sangat Setuju \\
\hline \hline
\end{tabular}

Perhitungan likert menghasilkan indeks rata rata 97\% dimana responden sangat setuju dengan faktor-faktor yang dimasukan kedalam kriteria kekuatan, kelemahan, peluang dan ancaman terhadap pengembangan industri Tenun Endek di Kecamatan Sidemen. Berdasarkan faktor-faktor diatas, analisa terhadap lingkungan internal dan eksternal yang digunakan sebagai landasan untuk mengetahui kelemahan, kelemahan, peluang dan tantangan dari Industri Tenun Endek. Berdasarkan hasil observasi terhadap karakteristik penyusunan table IFAS dan EFAS dilakukan dengan kuisioner riset SWOT yang memberikan bobot dan rating pada masing-masing faktor internal dan eksternal yang mempengaruhi pengembangan Industri Tenun Endek di Kecamatan Sidemen[9].

Tabel 5.

Perhitungan Skor SWOT

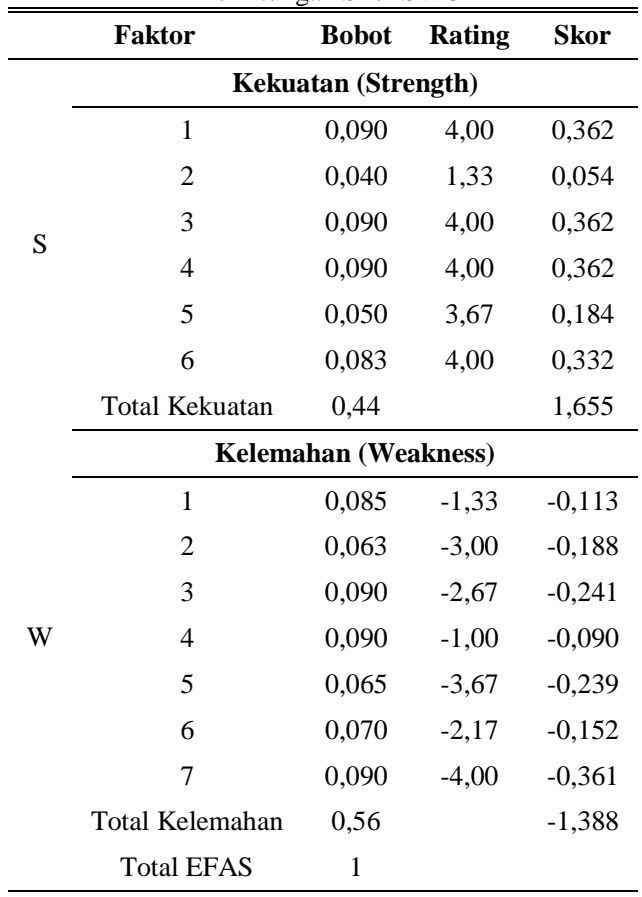

Koordinat $\mathrm{X}=$ (Skor kekuatan -Skor Kelemahan) $1,65+(-1,38)=0,267$

Faktor Bobot Rating Skor 


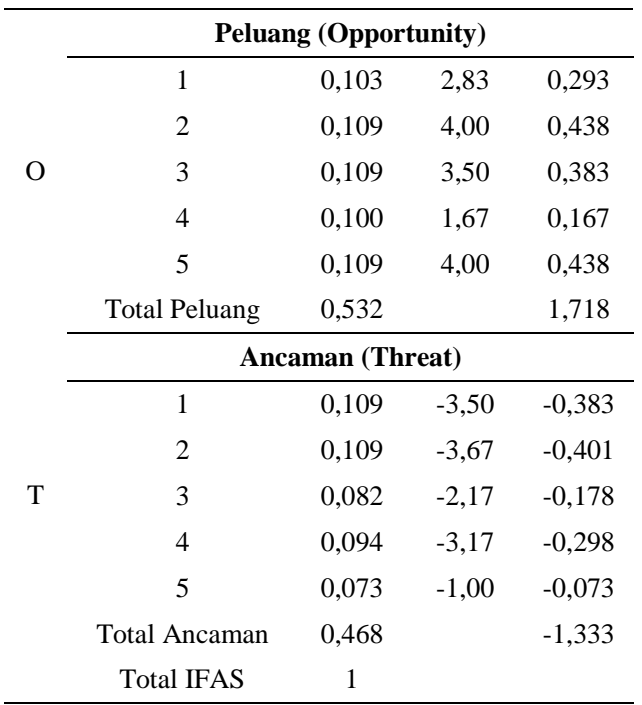

Koordinat $\mathrm{Y}=$ (Skor Peluang - Skor Ancaman $)$ $1,718+(-1,333)=0,385$

Berdasarkan hasil analisa faktor internal dan eksternal, faktor kekuatan memiliki total skor 1,65 faktor kelemahan memiliki total skor $-1,38$ faktor peluang memiliki total skor 1,718 dan faktor ancaman memiliki total skor $-1,333$ dari hasil analisa tersebut, dapat ditentukan koordinat pada diagram cartesius dengan kordinat $X$ pada nilai 0,267 dan kordinat $\mathrm{Y}$ berada pada nilai 0,385 yang bertujuan untuk memperoleh strategi yang tepat dalam Pengembangan Industri Tenun Endek Melalui Pendekatan One Village One Product di Kecamatan Sidemen Kabupaten Karangasem[9]. Hasil penentuan koordinat pada diagram cartesius SWOT adalah sebagai berikut:

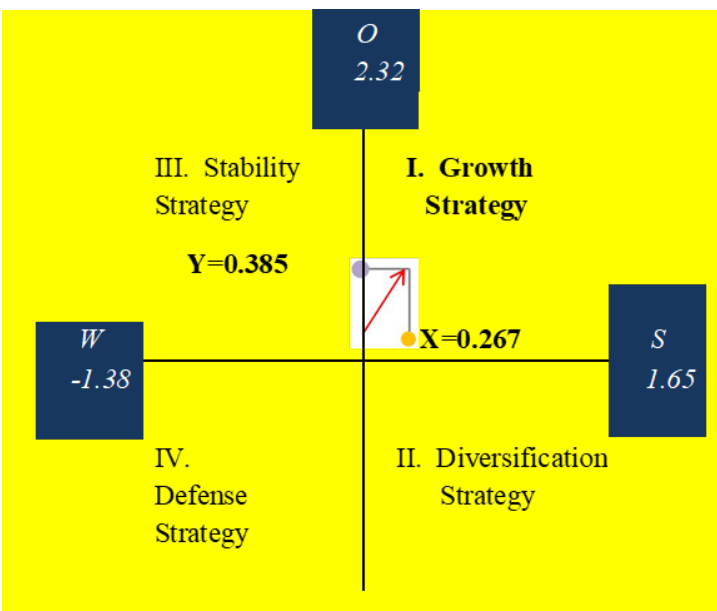

Gambar 1. Diagram Cartesius

Hasil analisa IFAS dan EFAS yang telah dilakukan menunjukkan jika strategi utama Pengembangan Industri Tenun Endek Melalui Pendekatan One Village One Product di Kecamatan Sidemen Kabupaten Karangasem adalah Growth Strategy karena berada di kuaran 1 dapat dikatakan ini adalah situasi yang sangat menguntungkan dimana kekuatan yang dimiliki Industri Tenun Endek dapat menjawab peluang yang dimiliki sehingga akan menjadi keuntungan untuk strategi pengembangan Industri Tenun Endek sendiri. Strategi dirumuskan menggunakan matriks SWOT dengan mensinkronisasikan antar variabel untuk membentuk strategi yang sesuai strategi yang tersusun dalam matriks SWOT dapat digolongkan dalam strategi utama dan strategi pendukung Pengembangan Industri Tenun Endek melalui Metode One Village One Product di Kecamatan
Sidemen. Rangkuman strategi yang tersusun dari hasil analisa pada matriks SWOT disajikan pada Table 6 .

Tabel 6.

Rangkuman Strategi

\begin{tabular}{clc}
\hline \hline \multicolumn{1}{c}{$\begin{array}{c}\text { Strategi Utama Pengembangan Industri Tenun Endek } \\
\text { melalui Metode One Village One Product di Kecamatan } \\
\text { Sidemen. }\end{array}$} & Kode \\
\hline 1 & $\begin{array}{l}\text { Menambah tenaga kerja dan memperluas lapangan kerja } \\
\text { untuk meningkatkan volume produksi. }\end{array}$ & SUT1 \\
2 & $\begin{array}{l}\text { Menyediakan pasar khusus yang mampu menampung } \\
\text { hasil produksi industri. }\end{array}$ & SUT2 \\
3 & $\begin{array}{l}\text { Mengintergrasikan Pasar khusus seni sebagai Objek } \\
\text { Wisata yang melibatkan proses produksi tenun endek. }\end{array}$ & SUT3 \\
4 & $\begin{array}{l}\text { Memperkuat produksi bahan mentah dalam daerah. } \\
5\end{array}$ & $\begin{array}{l}\text { Menyediakan desain produksi untuk kalangan tertentu } \\
\text { yang diproduksi khusus. }\end{array}$ \\
6 & $\begin{array}{l}\text { Meningkatkan penyediaan produk keluar daerah dengan } \\
\text { distribusi yang baik. }\end{array}$ & SUT5 \\
7 & $\begin{array}{l}\text { Meningkatkan penjualan secara Online untuk } \\
\text { menjangkau pasar yang lebih luas. }\end{array}$ & SUT7 \\
8 & $\begin{array}{l}\text { Pengembangan aplikasi jual beli yang mengatur pola } \\
\text { desain sesuai minat pelanggan. }\end{array}$ & SUT8 \\
\hline
\end{tabular}

Strategi Pendukung Pengembangan Industri Tenun Endek melalui Metode One Village One Product di Kecamatan Sidemen.

1 Mengadakan pelatihan kepada masyarakat dan tenaga $\quad$ SPE1 kerja mengenai produksi dan pemasaran.

2 Menciptakan kemasan yang menarik untuk SPE2 meningkatkan daya jual.

3 Menyediakan Lembaga Permodalan berupa koperasi yang mampu membantu pengembangan Industri Tenun Endek dan Industri lainnya.

4 Menciptakan kelompok usaha yang saling mendukung. SPE4

5 Pemerataan harga pasar untuk mengatur perekonomian $\quad$ SPE5 yang seimbang.

Untuk menentukan kesesuaian strategi dibuktikan dengan analisa delphi yang diterapkan kepada seluruh stakeholder terkait penelitian. Hasil analisa delphi menunjukan bahwa terdapat strategi pendukung yang tidak mencapai konsensus dikarenakan terdapat stakeholder yang menyatakan "Tidak Setuju”. Strategi tersebut adalah :

1. Menyediakan lembaga permodalan berupa koperasi yang mampu membantu pengembangan Industri Tenun Endek dan Industri lainnya.

2. Menciptakan kelompok usaha yang saling mendukung. Stakeholder

Tabel 7.

Iterasi tahap 1

\begin{tabular}{c|c|c|c|c|c|c|c}
\hline \hline No & Strategi & R1 & R2 & R3 & R4 & R5 & R6 \\
\hline 1 & SP3 & S & TS & S & S & S & TS \\
\hline 2 & SP4 & S & TS & S & TS & S & S \\
\hline \hline
\end{tabular}

Pernyataan tidak setuju dari stakeholder dikarenakan faktor lembaga permodalan sudah terdapatnya perbankan, citra koperasi negeri yang buruk di Karangasem dan tidak terstrukturnya susunan organisasi koperasi yang pernah dibentuk. Sedangkan faktor kelompok usaha tidak disetujui dikarenakan sebelumnya kelompok usaha sudah terbentuk tetapi tidak berjalan sesuai fungsinya, tidak adanya pengawasan langsung dari pemerintah dan kelompok usaha hanya beranggotakan pengerajin. Oleh karena itu berdasarkan pernyataan stakeholder dilakukan iterasi untuk mencapai konsensus.

Tabel 8.

Iterasi tahap 2

\begin{tabular}{c|c|c|c|c|c|c|c}
\hline \hline No & Strategi & R1 & R2 & R3 & R4 & R5 & R6 \\
\hline 1 & SP3 & S & S & S & S & S & S \\
\hline 2 & SP4 & S & S & S & S & S & S \\
\hline \hline
\end{tabular}

Setelah dilaksanakan iterasi 2 keseluruhan stakeholder menyetujui strategi dan mencapai konsensus dengan perubahan pada poin sebagai berikut :

1. Menyediakan Lembaga Permodalan yang dikelola 
Pemerintah daerah berupa koperasi bersama untuk membantu pengembangan Industri Tenun Endek dengan sistem yang memudahkan dan bunga minim dengan jangka waktu cicilan panjang.

2. Menciptakan kelompok usaha yang terstruktur dari berbagai elemen terkait untuk saling mendukung.

\section{KESIMPULAN}

Industri Tenun Endek di Kecamatan Sidemen Kabupaten Karangasem harus dikembangkan untuk menunjang perekonomian dan kesejahteraan masyaraka lokal. Strategi yang dirumuskan untuk pengembangan industri Tenun Endek di Kabupaten Karangasem merupakan strategi berjenis Growh Pole Strategy dirumuskan menjadi strategi utama dan strategi pendukung. Strategi didapat dengan memfokuskan kepada faktor kekuatan dan faktor peluang menjadi strategi utama. Strategi utama terdiri dari menambah tenaga kerja dan memperluas lapangan kerja untuk meningkatkan volume produksi., menyediakan pasar khusus yang mampu menampung hasil produksi industri daerah, mengintergrasikan Pasar khusus seni sebagai objek wisata yang melibatkan proses produksi tenun endek, memperkuat produksi bahan mentah dalam daerah, menyediakan desain produksi untuk kalangan tertentu yang diproduksi khusus, meningkatkan penyediaan produk keluar daerah dengan distribusi yang baik, meningkatkan penjualan secara online untuk menjangkau pasar yang lebih luasdan yang terakhir pengembangan aplikasi jual beli yang mengatur pola desain sesuai minat pelanggan. Sedangkan strategi pendukung terdiri dari mengadakan pelatihan kepada masyarakat dan tenaga kerja mengenai produksi dan pemasaran, menciptakan kemasan yang menarik untuk meningkatkan daya jual, menyediakan lembaga permodalan yang dikelola Pemerintah daerah berupa koperasi bersama untuk membantu pengembangan Industri Tenun Endek dengan sistem yang memudahkan dan bunga minim dengan jangka waktu cicilan panjang, menciptakan kelompok usaha yang terstruktur dari berbagai elemen terkait untuk saling mendukung, pemerataan harga pasar untuk mengatur perekonomian yang seimbang.

\section{DAFTAR PUSTAKA}

[1] M. Triharini, D. Larasati, and R. Susanto, "Pendekatan One Village One Product (OVOP) untuk mengembangkan potensi kerajinan daerah studi kasus: kerajinan gerabah di Kecamatan Plered, Kabupaten Purwakarta,” ITB J. Vis. Art Des., vol. 6, no. 1, pp. 29-42, 2014.

[2] Badan Pusat Statistik Karangasem, "Survei Sosial Ekonomi Nasional,” Karangasem, 2015.

[3] DISPERINDAG Karangasem, "Data Jumlah Industri Kecil dan Menengah Disperindag,” Karangasem, 2016.

[4] Badan Pusat Statistik Kabupaten Karangasem, Kabupaten Karangasem dalam Angka Tahun 2015. Karangasem: Badan Pusat Statistik Kabupaten Karangasem, 2015.

[5] Badan Pusat Statistik Karangasem, "PDRB Seri 2010 Menurut Lapangan Usaha,” Karangasem, 2010.

[6] R. Panggabean, "Pengembangan Koperasi dan UKM dengan Pendekatan OVOP,” INFOKOP, vol. 19, pp. 133-162, 2011.

[7] Y. Sugiharto and S. Rizal, Gerakan OVOP (One Village One Product) sebagai upaya peningkatan pembangunan daerah. Jakarta: Gramedia Pustaka Utama, 2008.

[8] Kementrian Koperasi dan UKM Republik Indonesia, "Pengembangan produk unggulan daerah dengan pendekatan one village one product melalui koperasi,” Jakarta, 2013.

[9] F. Rangkuti, Analisa SWOT teknik membedah kasus bisnis. Jakarta: Gramedia Pustaka Utama, 2006. 